\title{
CITRA DIRI PENYANDANG TUNANETRA TERHADAP DISKRIMINASI DARI LINGKUNGAN SOSIAL
}

\author{
Widya Lestari ${ }^{1}$ Rizki Fitlya ${ }^{2}$ \\ Email:widyalestari@unmuhpnk.ac.id ${ }^{1}$ \\ Program Studi Psikologi, Universitas Muhammadiyah Pontianak ${ }^{1,2}$
}

\begin{abstract}
Abstrak
Citra diri adalah konsep yang dibentuk di dalam pikiran mengenai seperti apa seseorang individu sebagai manusia sosial. Semua individu dapat menarik gambaran mental akan diri sendiri dan gambaran ini akan cenderung bertahan secara stabil seiring waktu kecuali individu tersebut mengambil langkah - langkah pertimbangan untuk mengubahnya. Individu dengan citra diri positif seringkali akan tampak lebih optimistik dalam hidup dan lebih percaya diri akan kemampuan diri karena merasakan kontrol yang lebih besar terhadap diri sendiri dan terhadap hidup begitu juga sebaliknya untuk citra diri negatif. Diskriminasi dari lingkungan tidak jarang terjadi pada penyandang tunanetra, sehingga hak-hak sebagai warga Negara sulit didapatkan Penelitian ini bertujuan untuk mengetahui citra diri penyandang tunanetra terhadap diskriminasi dari lingkungan sosial. Pendekatan yang digunakan dalam penelitian ini adalah deskriptif kualitatif dengan desain penelitian adalah studi kasus yang melibatkan 6 penyandang tunanetra. Teknik pengumpulan data yang digunakan adalah wawancara dan instrumen yang digunakan adalah kuesioner. Hasil penelitian menunjukkan pada dasarnya keenam subyek memiliki citra diri positif yang artinya subjek memiliki kepercayaan diri yang cukup baik, walaupun terkadang rasa percaya diri itu tidak stabil dikarenakan seringnya intensitas diskriminasi yang diterima. Secara keseluruhan keenam subjek memiliki ambisi atau rasa optimis dalam mencapai tujuan hidup dan cita-cita tetapi terkadang menjadikan beberpa subjek kurang dapat maksimal dalam mengorganisir diri. Hampir seluruh subjek merasa mampu untuk mencoba sesuatu yang baru dan dirasa orang lain bahwa subjek tidak dapat melakukannya. Kendali diri penyandang tunanetra cukup baik dalam menghadapi diskriminasi dimana subjek tidak mudah marah dan meluapkan emosinya di depan orang lain.
\end{abstract}

Kata Kunci: Citra Diri, Tunanetra, Diskriminasi

\begin{abstract}
Self-image is a concept that is formed in the mind about what an individual looks like as a social person. All individuals can draw mental images of themselves and these images will tend to hold steadily over time unless the individual takes steps to consider changing them. Individuals with a positive self-image will often appear more optimistic in life and more confident in their abilities because they feel more control over themselves and over life and vice versa for negative self-images. Discrimination from the environment often occurs in visually impaired persons, so that their rights as citizens are difficult to obtain. This study aims to determine the self-image of blind persons against discrimination from the social environment. The approach used in this research is descriptive qualitative research design is a case study involving 6 blind people. The data collection technique used was an interview and the instrument used was a questionnaire. The results showed that basically the six subjects had a positive self-image, which means that the subjects had a fairly good self-confidence, although sometimes that self-confidence was unstable due to the frequent intensity of discrimination received. Overall, the six subjects have ambition or a sense of optimism in achieving life goals and ideals but sometimes make some subjects less able to organize themselves optimally. Almost all subjects felt able to try something new and other people felt that the subject could not do it. Blind persons self-control is quite good in dealing with discrimination where the subject does not get angry easily and expresses his emotions in front of other people.
\end{abstract}

Keyword: Self-Image, Visually Impaired, Discrimination

\section{PENDAHULUAN}

Tunanetra adalah istilah umum yang digunakan untuk kondisi seseorang yang mengalami gangguan atau hambatan dalam indra penglihatannya. Berdasarkan tingkat gangguannya Tunanetra dibagi dua yaitu buta total (total blind) dan yang masih mempunyai sisa penglihatan (Low 
Visioan). Akibat hilang atau berkurangnya fungsi indra penglihatannya maka tunanetra berusaha memaksimalkan fungsi indra-indra yang lainnya seperti, perabaan, penciuman, pendengaran, dan lain sebagainya sehingga tidak sedikit penyandang tunanetra yang memiliki kemampuan luar biasa misalnya di bidang musik atau ilmu pengetahuan. Pada zaman sekarang ini telah banyak penyandang disabilitas termasuk tunanetra yang memiliki kemampuan sama bahkan lebih dari individu normal lainnya.

Kemampuan yang dimiliki seorang tunanetra mungkin saja dapat meningkatkan citra dirinya. Citra diri merupakan bagian dari konsep diri, yaitu yang berhubungan dengan konsep diri secara kognitif. Citra diri yang dimaksud adalah sebuah anggapan atau pengetahuan yang tertanam di alam bawah sadar individu tentang penampilan dirinya, hal itu selain dinilai oleh dirinya sendiri juga dinilai orang lain. Perkembangan fisik, psikis dan psikososial yang terjadi pada setiap individu menentukan bagaimana individu tersebut mulai mengembangankan citra dirinya. Membangun citra diri sangatlah penting, apalagi untuk penyandang tunanetra yang tetap harus berinteraksi dengan lingkungan sosial.
Di sisi lain, penyandang tunanetra masih saja sering mendapatkan perlakuan diskriminasi dari lingkungan sosial seperti dikucilkan, tidak mendapatkan hak dalam pendidikan, tidak bisa bersosialisasi dengan baik di lingkungan, kurang mendapatkan prioritas dalam fasilitas umum dan hak-hak lainnya yang pada dasarnya harus didapatkan oleh penyandang tunanetra. Keadaan tunanetra yang mendapatkan perlakuan diskriminasi sering terjadi di kehidupan sosial, sebagai contoh diskriminasi yang dialami oleh $\mathrm{F}$ salah satu penyandang tunanetra yang berada di kota Pontianak. Saat akan mendaftar kuliah pada salah satu perguruan tinggi di Pontianak, F mendapatkan perlakuan diskriminasi berupa penolakan dari pihak fakultas dikarenakan $\mathrm{F}$ merupakan penyandang tunanetra. Hal tersebut bertentangan dengan Undang-undang RI no 8 tahun 2016 pasal 5 tentang penyandang disabilitas yang menyatakan hak disabilitas salah satunya adalah hak mendapatkan pendidikan.

Kejadian lain yang dialami oleh $\mathrm{F}$ yaitu ketika akan melakukan perjalanan menggunakan pesawat, pihak maskapai meminta $\mathrm{F}$ untuk menandatangani surat yang menyatakan bahwa pihak maskapai tidak bertanggungjawab atas $\mathrm{F}$ ketika di dalam pesawat, sehingga $\mathrm{F}$ harus 
melaporkan keadaan tersebut kepada pimpinan bandara untuk mendapatkan hak sebagai penumpang. Beberapa kejadian tersebut menjadikan $\mathrm{F}$ berfikir bahwa banyak lingkungan yang melakukan diskriminasi terhadap penyandang disabilitas khususnya pada F. Jika diskriminasi yang dialami oleh tunanetra sering terjadi bisa saja mempengaruhi penyandang tunanetra dalam melihat citra dirinya. Hasil penelitian Ika Heriani menyatakan bahwa label negatif dan diskriminasi yang diterima menjadikan ODHA memiliki konsep diri negatif. Konsep diri sangat berhubungan dengan citra diri, sehingga citra diri yang baik sebenarnya bisa dibangun dengan komunikasi antar pribadi dan pergaulan yang baik dengan siapa saja.

Berdasarkan penjelasan yang telah dipaparkan sebelumnya, maka menarik peneliti untuk melakukan penelitian dan mengetahui citra diri penyandang tunanetra terhadap diskriminasi dari lingkungan sosial.

\section{KAJIAN PUSTAKA}

\section{Citra diri}

Citra Diri adalah cara seseorang melihat atau menilai tentang penampilan dirinya (kemenarikan tubuhnya) Setiap orang akan mempunyai citra diri tentang dirinya sendiri, baik tentang citra diri yang sebenarnya (real self), maupun citra diri yang diinginkannya (ideal self). Kemampuan yang dimiliki, keadaan lingkungan, dan sikap serta pendapat pribadinya akan mempegaruhi seseorang dalam bentuk citra dirinya (Burns).

Brown (1998) mengungkapkan bahwa ada tiga aspek dalam pengetahuan akan diri sendiri yaitu:

a. Dunia fisik (physical world)

Realitas fisik dapat memberikan suatu arti yang mana kita dapat belajar mengenai diri kita sendiri. Sumber pengetahuan dari dunia fisikal memberikan pengetahuan diri sendiri. Akan tetapi pengetahuan dari dunia fisik terbatas pada atribut yang bisa diukur dengan yang mudah terlihat

dan bersifat subjektif dan kurang bermakna jika tidak dibandingkan dengan individu lainnya.

b. Dunia Sosial (social world)

Sumber masukan untuk mencapai pemahaman akan citra diri adalah masukan dari lingkungan sosial individu. Proses pencapaian pemahaman diri melalui lingkungan sosial tersebut ada dua macam, yiatu:

1) Perbandingan Sosial (social comparison) Serupa dengan dunia fisik, dunia sosial juga membantu memberi gambaran diri melalui perbandingan dengan orang lain.

2) Penilaian yang tercerminkan (reflected apraisal) Pengetahuan akan diri individu 
tercapai dengan cara melihat tanggapan orang lain terhadap perilaku individu.

c. Dunia dalam atau psikologis (inner/ psychologycal world)

Sedangkan untuk sumber berupa penilaian dari dalam diri individu,ada tiga hal yang dapat mempengaruhi pencapaian pemahaman akan citra diri individu, yaitu:

1. Instrospeksi (introspection)

2. Proses mempersepsi diri (self perception process)

3. Atribusi kausal (causal attributions)

Citra diri adalah bagaimana seseorang melihat dirinya sendiri, bagaimana bayangan atau gambaran tentang diri seseorang individu itu sendiri mengenai dirinya (Jersild, 1961). Komponen-komponen citra diri menurut Jersild (1961), diantaranya:

\section{a. Perceptual Component \\ b. Conceptual Component \\ c. Attitudional Component}

Komponen ini merupakan pikiran dan perasaan seseorang mengenai dirinya, status, dan pandangan terhadap orang lain. komponen ini disebut sebagai social self image.

James K.Van fleet (1997) merupakan tokoh terkemuka dalam bidang psikologi, mengidentifikasikan citra diri yang positif dan negatif, yaitu :

\section{a. Citra Diri Positif}

1. Memiliki rasa percaya diri yang kuat.
2. Berorientasi pada ambisi yang kuat dan mampu menentukan sasaran hidup.

3. Terorganisir dengan baik dan efisien (tidak terombang ambing lagi tanpa tujuan dari hari ke hari).

4. Bersikap mampu.

5. Memiliki kepribadian yang menyenangkan.

6. Mampu mengendalikan diri.

b. Citra Diri Negatif

1. Merasa rendah diri.

2. Kurang memiliki dorongan dan semangat hidup.

3. Lebih suka menunda waktu.

4. Memiliki landasan yang pesimistik dan emosi negatif.

5. Pemalu dan menyendiri (karena mendapat kritik dari orang lain, hinaan dan ejekan dari teman).

6. Hanya memiliki kepuasan sendiri. Seseorang dengan citra diri yang positif tidak akan menyangkal kekurangan dirinya sebagai faktor yang mempengaruhi konsep diri. Individu akan realistis dan sangat memahami dan menerima fakta bahwa mereka juga memiliki masalah pribadi, namun tidak ada penilaian kritis mengenainya. Mereka menerima dan mengetahui siapa dirinya dan bagaimana dirinya pada saat itu dan melakukan yang terbaik dengan apa yang dimiliki. Citra diri yang positif tentunya 
terbangun diatas harga diri yang tinggi, dan keduanya akan berfungsi bersama untuk membentuk kepribadian yang sehat dan secara efektif membentuk dasar akan kehidupan yang berdaya.

\section{Diskriminasi}

Diskriminasi mengandung arti perlakuan tidak seimbang terhadap sekelompok orang, yang pada hakekatnya adalah sama dengan kelompok pelaku diskriminasi. Menurut Baron \& Donn (2003) diskriminasi dapat berakar dari sikap implisit yang terpicu secara otomatis dan stereotip (sikap di mana individu tidak menyadarinya). Diskriminasi di Indonesia juga diatur dalam suatu susunan UUD, Secara formal pengertian diskriminasi diatur di dalam UU No. 39 Tahun 1999 tentang Hak Asasi Manusia yang terdapat pada pasal 1 ayat (3).

Diskriminasi terhadap penyandang disabilitas tidak jarang terjadi, khususnya dalam hal mendapatkan lapangan pekerjaan, pendidikan dan fasilitas umum. Bentuk diskriminasi dari lembaga pendidikan dan pelayanan umum adalah penolakan untuk mendapatkan hak pendidikan, kurangnya prioritas dan pendampingan saat penggunaan transportasi umum, sulitnya mendapatkan pekerjaan yang layak.

\section{Tunanetra}

Menurut Daniel P. Hallahan, James M. Kauffman, dan Paige C. Pullen (2009), mengemukakan "Legally blind is a person who has visual acuity of 20/200 or less in the better eye even with correction (e.g., eyeglasses) or has a field of vision so narrow that its widest diameter subtends an angular distance no greater than 20 degrees". Definisi tersebut dapat dikemukakan bahwa anak buta adalah seseorang yang memiliki ketajaman visual 20/200 atau kurang pada mata/penglihatan yang lebih baik setelah dilakukan koreksi (misalnya kacamata) atau memiliki bidang penglihatan begitu sempit dengan diameter terlebar memiliki jarak sudut pandang tidak lebih dari 20 derajat.

\section{Karakteristik Penyandang Tunanetra}

Menurut Aqila Smart (2010: 39-

40) karakteristik penyandang tunanetra yaitu: 1) perasaan mudah tersinggung; 2) mudah curiga; dan 3) ketergantungan yang berlebihan. Karakteristik tersebut dapat dikaji dan dimaknai lebih lanjut sebagai berikut:

a. Perasaan mudah tersinggung

Perasaan mudah tersinggung yang dirasakan oleh penyandang tunanetra disebabkan kurangnya rangsangan visual yang diterimanya sehingga individu merasa emosional ketika seseorang membicarakan hal-hal yang tidak bisa ia lakukan dan dengar

b. Mudah curiga 
Pada tunanetra rasa kecurigaannya melebihi orang pada umumnya. Anak tunanetra merasa curiga terhadap orang yang ingin membantunya. Hal ini bahwa untuk mengurangi atau menghilangkan rasa curiganya, seseorang harus melakukan pendekatan terlebih dahulu kepadanya agar anak tunanetra mengenal dan memahami sikap orang lain.

c. Ketergantungan yang berlebihan

Anak tunanetra dalam melakukan suatu hal yang bersifat baru membutuhkan bantuan dan arahan agar dapat melakukannya, namun bantuan dan arahan tersebut tidak dapat dilakukan secara terus menerus. Hal ini dilakukan oleh anak tunanetra yang memiliki asumsi bahwa dengan bantuan orang lain terutama mobilitas merasa lebih aman, sehingga akan menjadikan anak tunanetra memiliki ketergantungan secara berlebihan kepada orang awas terutama pada hal-hal yang anak tunanetra dapat melakukan secara mandiri.

\section{Keterbatasan Anak Tunanetra}

Menurut Juang Sunanto (2005) kehilangan penglihatan mengakibatkan tiga keterbatasan yang serius yaitu; 1) variasi dan jenis pengalaman (kognisi); 2) kemampuan untuk bergerak; dan 3) interaksi dengan lingkungan (sosial dan emosi). Tiga keterbatasan tersebut dapat dikaji dan dimaknai lebih lanjut sebagai berikut:

a. Variasi dan jenis pengalaman

Anak tunanetra memperoleh pengalaman melalui taktual/perabaan dan indera pendengaran, sedangkan anak awas melalui pengalaman visual dalam memperoleh informasi secara lebih lengkap dan rinci, sehingga hal ini berpengaruh pada variasi dan jenis pengalaman anak yang membutuhkan strategi dan kemampuan anak dalam memahami informasi tersebut.

b. Kemampuan untuk bergerak

Keterbatasan penglihatan sangat mempengaruhi kemampuan untuk bergerak (mobilitas) dalam kehidupan sehari-hari.

c. Berinteraksi dengan lingkungannya (sosial dan emosi). Anak tunanetra yang mengalami permasalahan dalam interaksi dengan lingkungan dipengaruhi oleh sikap orang tua, keluarga dan masyarakat terhadapnya yakni kurang adanya penerimaan dan komunikasi yang baik.

\section{METODE PENELITIAN}

Penelitian ini dilakukan dengan pendekatan kualitatif. Desain penelitian adalah studi kasus, dengan melibatkan penyandang tunanetra. Melalui penelitian ini peneliti ingin mengetahui citra diri tunanetra terhadap diskriminasi dari lingkungan sosial. 
Penelitian ini dibagi menjadi lima tahap. Alur penelitian ini dapat dilihat pada Gambar 1.

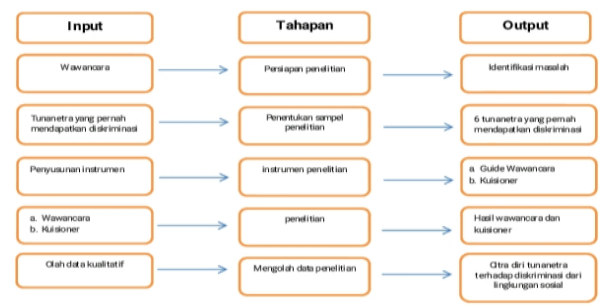

Gambar 1. Tahapan penelitian

Penelitian ini dilakukan selama dua belas bulan pada tahun 2020. Lokasi penelitian dilakukan di Yayasan ArRahma dimana subjek penelitian biasanya mendapatkan materi atau ilmu tambahan selain ilmu di pendidikan formal.

Pemilihan sample dengan menggunakan purposive sampling. Teknik ini dipilih karena peneliti memilih partisipan berdasarkan tujuan permasalahan penelitian yang akan dikaji (Iskandar, 2009). Dimana peneliti mengambil sejumlah kasus kecil dari kasus yang homogen (Poerwandari, 2007).

Pemilihan sample tetap berpegang pada tujuan penelitian yaitu untuk mengetahui citra diri tunanetra terhadap diskriminasi dari lingkungan sosial, maka pemilihan sampel yang digunakan dalam penelitian ini adalah subjek yang memiliki karakteristik sebagai berikut:

1. Subjek mengalami kecacatan pada organ mata sejak lahir maupun karena kecelakaan.
2. Subjek pernah mendapat diskriminasi dari lingkungan sosial

Penelitian ini menggunakan teknik pengumpulan data:

1. Wawancara terstruktur, yaitu pengumpulan data dengan menggunakan instrument kuisioner.

2. Wawancara semi tersruktur, yaitu pengumpulan data dengan menggunakan guide wawancara

3. Kuisioner menggunakan huruf braille bertujuan agar subjek penelitian dapat mengungkapkan jawaban sesuai dengan apa yang dirasakan dan tidak dapat diungkapkan melalui wawancara.

Data-data kualitatif pada penelitian ini dianalisis melalui langkah-langkah (Creswell, 2010) sebagai berikut:

1. Mengolah dan mempersiapkan data untuk dianalisis

2. Membaca keseluruhan data

3. Menganalisis lebih detil dengan mengcoding data

4. Menerapkan proses coding untuk mendeskripsikan setting, orangorang, kategori-kategori, dan tema-tema yang dianalisis.

5. Mendeskripsikan dan menghubungkan tema-tema dalam narasi atau laporan kualitatif serta interpretasi data. 


\section{HASIL DAN PEMBAHASAN}

Penelitian ini menggunakan metode studi kasus yang diukur dengan menggunakan kuisioner penelitian yang telah peneliti buat. Penelitian dimulai dengan cara mewawancarai subjek penelitian berdasarkan pedoman wawancara dan kuisioner yang di jawab oleh subjek penelitian menggunakan alat bantu reglet dengan tujuan agar subjek penelitian dapat mengungkapkan perasaan dan pengalaman yang dirasakan melalui tulisan huruf braille. Kuisioner terdiri dari 6 pertanyaan inti untuk mengungkap citra diri tunanetra. Penelitian dilakukan dengan cara bertemu dengan subjek di Yayasan Ar-Rahmah dimana tempat tersebut merupakan rumah tempat beberapa penyandang tunanetra mendapatkan ilmu selain di sekolah.

Pengumpulan data penelitian dapat dilakukan dengan lancar karena subjek penelitian dapat bersikap kooperatif dan menerima kehadiran peneliti. Pertemuan dilakukan 2 hingga 3 kali untuk setiap subjek penelitian hal itu dilakukan untuk membangun perasaan nyaman dan percaya antara subjek penelitian ke peneliti. Pada pertemuan pertama peneliti bertemu dengan subjek penelitian untuk menyampaikan sistematika penelitian yang akan di lakukan dan jadwal pertemuan selanjutnya untuk masing- masing subjek. Pertemuan selanjutnya peneliti bertemu dengan subjek penelitian secara bergantian sesuai kesepakatan jadwal pertemuan.

Data-data kualitatif pada penelitian ini dianalisis melalui langkah-langkah (Creswell, 2010) sebagai berikut:

1. Mengolah dan mempersiapkan data untuk dianalisis

Data merupakan bagian penting dari suatu penelitian. Data yang telah didapatkan pada saat proses pengumpulan data kemudian diurutkan berdasarkan nomor urutan subjek penelitian untuk dapat dianalisis secara kualitatif.

2. Membaca keseluruhan data

Data yang telah dikumpulkan dan dipersiapkan untuk diolah haruslah dibaca terlebih dahulu secara menyeluruh agar peneliti yakin bahwa data yang sudah diambil telah lengkap dan siap untuk diolah.

3. Menganalisis lebih detil dengan mengcoding data

Setelah data disiapkan dengan legkap, langkah selanjutnya adalah mengkoding atau memberikan kode pada data agar lebih mudah untuk dianalisis. Kode dibuat berdasarkan aspek dari citra diri yaitu:
a. Rasa percaya diri (PD)
b. Ambisi (AM)
c. Organisir Diri (OD) 
d. Sikap mampu (MP)

e. Kepribadian (KP)

f. Kendali diri (KD)

4. Menerapkan proses coding untuk mendeskripsikan setting, orang-orang, kategori-kategori, dan tema-tema yang dianalisis.

Pada tahap ini, proses coding dilakukan untuk menentukan muncul atau tidaknya aspek yang diukur. Coding dibuat berdasarkan hasil wawancara subjek untuk mendiskripsikan aspek dan gambaran makna hasil wawancara. Selain proses coding berdasarkan aspek, peneliti juga menggunakan analisis diagnostik dimana di dalam analisis tersebut adalah kode untuk memberikan gambaran makna dari hasil wawancara contohnya coding "semangat tinggi" untuk subjek yang menunjukkan hasil wawancara "Semangat sih ada, besar dan tetap semangat, diskriminasi jadikan motovasi”.

5. Mendeskripsikan dan interpretasi data

Tabel 1. Tema-tema Citra diri Penyandang Tunanetra Terhadap Diskriminasi Lingkungan Sosial

\begin{tabular}{|l|c|c|c|c|c|c|}
\hline \multicolumn{1}{|c|}{ Tema } & S 1 & S 2 & S 3 & S 4 & S 5 & S 6 \\
\hline $\begin{array}{l}\text { Rasa } \\
\text { percaya diri } \\
\text { (PD) }\end{array}$ & ++ & ++ & ++ & ++ & + & + \\
\hline $\begin{array}{l}\text { Ambisi } \\
\text { (AM) }\end{array}$ & ++ & +++ & ++ & +++ & ++ & ++ \\
\hline $\begin{array}{l}\text { Organisir } \\
\text { Diri (OD) }\end{array}$ & ++ & + & +++ & ++ & + & + \\
\hline $\begin{array}{l}\text { Sikap } \\
\text { mampu } \\
\text { (MP) }\end{array}$ & +++ & +++ & ++ & + & +++ & +++ \\
\hline $\begin{array}{l}\text { Kepribadian } \\
\text { (KP) }\end{array}$ & ++ & ++ & ++ & + & ++ & + \\
\hline $\begin{array}{l}\text { Kendali diri } \\
\text { (KD) }\end{array}$ & + & +++ & +++ & ++ & +++ & + \\
\hline
\end{tabular}

Berdasarkan tabel 1 di atas dapat dilihat bahwa pada dasarnya keenam subyek memiliki citra diri positif yang artinya subjek memiliki kepercayaan diri yang cukup baik, walaupun terkadang rasa percaya diri itu tidak stabil dikarenakan seringnya intensitas diskriminasi yang diterima. Secara keseluruhan keenam subjek memiliki ambisi atau rasa optimis dalam mencapai tujuan hidup dan cita-cita tetapi terkadang menjadikan beberpa subjek kurang dapat maksimal dalam mengorganisir diri. Hampir seluruh subjek merasa mampu untuk mencoba sesuatu yang baru dan dirasa orang lain bahwa subjek tidak dapat melakukannya. Beberapa subjek dapat menilai pribadi diri dengan cukup baik, ada juga subjek yang menilai diri sebagai seseorang yang menilai diri kurang baik hal tersebut dikarenakan diskriminasi yang semakin sering diterima oleh subjek. Kendali diri penyandang tunanetra cukup baik dalam menghadapi diskriminasi dimana subjek tidak mudah marah dan meluapkan emosinya di depan orang lain.

Pembahasan keenam subyek di atas dapat diketahui bahwa masingmasing subyek memiliki pemikiran yang berbeda dalam menanggapi citra diri berdasarkan pengaruh diskriminasi dari lingkungan sosial. Latar belakang yang dimiliki masing-masing subyek dan 
intensitas seringnya menerima diskriminasi menjadikan citra diri subjek berbeda antar yang satu dengan lainnya. Pengalaman hidup dapat menyebabkan seseorang memiliki citra diri yang baik. Begitu pula dalam menghadapi permasalahan diskriminasi sosial dan proses bertindak harus dilakukan secara lebih positif dalam mencari solusi penyelesaian membuat individu dinilai matang dalam berfikir dan bertindak.

\section{PENUTUP}

\section{Kesimpulan}

Tunanetra merupakan suatu kondisi dimana seseorang kehilangan penglihatan. Kekurangan penglihatan pada seseorang haruslah di dukung oleh orangorang disekitarnya. Namun disisi lain penyandang tunanetra sering mendapatkan diskriminasi dari lingkungan sekitar berpengaruh terhadap cara pandang diri penyandang tunanetra itu sendiri. Penyandang tunanetra dalam penelitian ini secara keseluruhan cukup dapat menilai citra diri positif walaupun terkadang ada perasaan yang kurang stabil dikarenakan seringnya diskriminasi yang didapatkan dari lingkungan sosial. Keterbatasan penglihatan yang dimiliki penyandang tunanetra tidak menurunkan keinginan dan semangat untuk menunjukkan kemampuan yang dimiliki.

\section{Saran}

Melihat hasil penelitian yang diperoleh, maka peneliti memiliki beberapa saran :

\section{Saran Metodologis}

a. Untuk mendapatkan hasil yang lebih baik, disaarankan untuk peneliti selanjutnya tidak hanya menggunakan metode wawancara tapi bisa menggunakan asesmen lainnya sebagai tambahan dokumen penelitian.

b. Perlu uji keabsahan data untuk penelitian lanjutan dengan menggunakan alat bantu berupa pengumpulan data informasi tambahan dari pihak-pihak lain yang terkait seperti keluarga, teman, serta dokumentasi pribadi seperti catatan harian subyek, agar data lebih akurat

c. Diharapkan peneliti selanjutnya agar dalam melakukan wawancara lebih mendalam agar lebih mendapatkan data yang lebih lengkap.

\section{Saran Praktis}

a. Perlunya dukungan dari keluarga dan lingkungan sosial lainnya untuk memperkuat citra diri penyandang tuna netra

b. Perlunya pelatihan pelatihanpelatihan dasar mengenai pengendalian emosi dan pengenalan 
pribadi diri bagi penyandang tunanetra

\section{DAFTAR PUSTAKA}

Arikunto, S. 2010. Prosedur Penelitian Suatu Pendekatan Praktik. Jakarta: Rineka Cipta.

Aqila Smart. 2010. Anak Cacat Bukan Kiamat, Pendekatan Pembelajaran \& Terapi untuk Anak Berkebutuhan Khusus. Yogyakarta: Katahati.

Baron, R.A. dan Donn. B. 2003. Psikologi Sosial. Jakarta: Erlangga

Brown, J.D. 1998. The Self. Massachussetts: Mc.Graw Hill Inc.

Creswell, J. W. 2010. Research Design: Pendekatan Kualitatif, Kuantitatif, Dan Mixed. Yogjakarta: PT Pustaka Pelajar.

Daniel P. Hallahan, James M. Kauffman \& Paige C. Pullen. 2009. Exceptional Learner An Introduction to Special Education. United States of America: PEARSON.

Fristy.2012. Citra Diri pada Remaja Putri Yang Mengalami Kecenderungan Gangguan Body Dismorphic. Jurnal Fakultas Psikologi Universitas Gunadarma, 14(2), 1-11

Fleet, James K. Van. 1997. Cara Meraih Pengaruh dan Kekuasaan Tak Terbatas dalam 21 Hari. Cet. Ketiga. Jakarta: Penerbit Mitra Utama.
Herani, Sarikusuma, dan Hasanah.2012. Konsep diri orang dengan HIV dan AIDS (ODHA) yang menerima label negatif dan diskriminasi dari lingkungan sosial. Jurnal Psikologia-online Vol. 7, No. 1, hal. 29-40. http://id.portalgaruda.org.5 Agustus 2019

Iskandar. 2009. Metodologi Penelitian Kualitatif. Jakarta: Gaung Persada Press.

Juang Sunanto.2005. Mengembangkan Potensi Anak Berkelainan Penglihatan. Departemen Pendidikan Nasional Direktorat Jenderal Pendidikan Tinggi Direktorat Pembinaan Pendidikan Tenaga Kependidikan dan Ketenagaan Perguruan Tinggi.

Poerwandari, K. 2007. Pendekatan Kualitatif Dalam Penelitian Psikologi. Jakarta: PSP3 Fakultas Psikologi Universitas Indonesia. 